\title{
Pemberian Kuasa Lisan Untuk Mewakili Pemegang Saham Dalam Rapat Umum Pemegang Saham
}

\author{
Darmawati \\ Magister Kenotariatan, Fakultas Hukum Universitas Surabaya \\ Email: darmawati_dahlan@ymail.com
}

\begin{abstract}
Power of attorney establishment accomodates and helps someone who is hindered to execute their rights and obligations directly. Those limitations can be solved by giving a power of attorney to other people as an endorsee. Giving a power of attorney can be done in writing or verbally. To proof a power of attorney which was given verbally is actually very difficult. Considering that a power of attorney by verbal is simpler, there is a lot of people who is doing so, with no exception is shareholders in a limited company who give a power of attorney verbally to someone to represent them in a General Meeting of Shareholder. An endorsee who receives a power of attorney verbally from shareholders, which is difficult to proof, will represent shareholders' voting rights in a General Meeting of Shareholder to fulfill meeting quorum and give voting rights in shareholders decision making.
\end{abstract}

Keyword: Limited Company, Power of Attorney, General Meeting of Shareholder.

Abstrak. Lembaga kuasa mengakomodasi dan membantu seseorang yang terhalang untuk melaksanakan hak dan kewajibannya secara langsung. Keterbatasan tersebut dapat diselesaikan dengan memberikan kuasa kepada orang lain sebagai penerima kuasa. Pemberian kuasa dapat dilakukan secara tertulis ataupun lisan. Pembuktian pemberian kuasa secara lisan sendiri sebenarnya sangat sulit. Mengingat pemberian kuasa secara lisan yang lebih sederhana, cukup banyak orang yang melakukannya, tidak terkecuali pemegang saham dalam perseroan terbatas yang memberikan kuasa secara lisan kepada seseorang untuk mewakilinya dalam Rapat Umum Pemegang Saham. Penerima kuasa secara lisan dari seorang pemegang saham, yang sulit pembuktiannya, akan mewakili hak suara pemegang saham tersebut dalam Rapat Umum Pemegang Saham untuk memenuhi persyaratan kuorum kehadiran dan memberikan suara mereka pada pengambilan keputusan pemegang saham.

Kata kunci : Perseroan Terbatas, Kuasa, Rapat Umum Pemegang Saham.

\section{PENDAHULUAN}

\section{Latar Belakang Umum}

Dalam kehidupan sehari-hari karena kesibukan yang begitu padat, kadang-kadang seseorang mengalami kesulitan untuk melaksanakan hak dan kewajibannya. Mereka yang tidak dapat melaksanakan hak dan kewajibannya secara langsung tersebut dapat memberikan kuasa kepada seorang yang lain untuk mewakilinya (Wicaksono, 2009). Lembaga kuasa memang sangat dibutuhkan dalam kehidupan masyarakat yang serba komplek pada masa kini, untuk memudahkan seseorang yang secara langsung tidak dapat melaksanakan hak dan kewajibannya dalam lalu lintas hukum, dikarenakan terbatasnya waktu, jauhnya jarak, keadaan fisik, keadaan sosial ekonomi dan lainnya (Latumeten, 2017).

Pemberian kuasa dalam kehidupan bermasyarakat dewasa ini sering ditemukan dalam hal seseorang sebagai pemegang saham memberikan kuasa kepada seorang yang lain untuk mewakilinya dalam Rapat Umum Pemegang Saham (selanjutnya disebut RUPS). Pemberian kuasa untuk mewakili pemegang saham dalam RUPS dilakukan mengingat bahwa pemegang saham selaku pemberi kuasa memiliki hak suara dalam RUPS tersebut.

Hak suara pemegang saham dalam RUPS sangatlah penting untuk memenuhi 
syarat kuorum kehadiran dan pengambilan sebuah keputusan dalam RUPS. Hasil akhir keputusan sebuah RUPS sendiri memiliki arti yang juga penting, mengingat wewenang pengambilan keputusan tersebut akan menentukan arah, jalan kerja, dan perbuatan hukum yang akan diambil oleh Perseroan Terbatas (selanjutnya disebut PT). Mengingat urgensitas hak suara pemegang saham dalam RUPS, hak suara tersebut sangat rentan untuk disalahgunakan oleh orang yang tidak bertanggung jawab, tidak terkecuali oleh penerima kuasa yang memperoleh kuasa dari pemegang saham. Mekanisme pemberian kuasa yang paling mudah untuk disalahgunakan menurut penulis adalah pemberian kuasa secara lisan. Oleh sebab itu, penulis ingin membahas lebih lanjut mengenai pemberian kuasa secara lisan untuk mewakili pemegang saham dalam RUPS.

\section{State of The Art}

Salah satu contoh penelitian yang relevan untuk digunakan sebagai komparasi adalah penelitian yang disusun Purry Wulandari (2010) dengan judul "Pemberian Kuasa Lisan untuk Melakukan Perbuatan Hukum yang Mengatasnamakan PT kepada Manajer Pemasaran (Studi Kasus Wanprestasi Perjanjian Jual Beli dengan Kuasa Lisan yang Diberikan Direksi kepada Manajer Pemasaran dalam PT Y)". Penelitian tersebut pada dasarnya juga membahas pemberian kuasa lisan sebagaimana yang menjadi pokok bahasan penelitian ini.

Namun kuasa lisan yang dibahas dalam penelitian tersebut adalah dalam hubungannya dengan perbuatan hukum yang dilakukan Manajer Pemasaran atas nama PT. Konteksnya berbeda dengan penelitian ini yang membahas kuasa lisan dalam hubungannya dengan tidak dapat hadirnya pemegang saham dalam RUPS sehingga harus diwakili oleh penerima kuasa tertentu yang ditunjuk.

\section{METODE PENELITIAN}

Metode penelitian yang digunakan adalah dengan menggunakan metode penelitian yuridis normatif. Tipe penelitian yuridis normatif sendiri didasarkan pada norma-norma hukum positif untuk mendapatkan kebenaran yang bersifat koherensi (Marzuki, 2015). Konsepsi ini memandang hukum sebagai suatu sistem normatif yang bersifat mandiri, tertutup dan terlepas dari kehidupan masyarakat yang nyata (Soemitro, 1988).

Pendekatan hukum yang digunakan adalah melalui pendekatan peraturan perundang-undangan (statute approach) dan pendekatan konseptual (conseptual approach). Pendekatan peraturan perundangundangan dilakukan dengan cara menelaah undang-undang dan peraturan terkait yang mengatur isu hukum yang sedang diteliti. Pendekatan konseptual dilakukan dengan menganalisa isu hukum berdasarkan teoriteori hukum doktrin para sarjana, dan putusan pengadilan (yurisprudensi).

Penelitian ini diawali dengan mengumpulkan bahan hukum baik bahan hukum primer dan bahan hukum sekunder, kemudian dilanjutkan dengan elakukan sistematisasi hukum. Selanjutnya terhadap bahan hukum tersebut akan dilakukan analisis bahan hukum secara deduktif dan penafsiran hukum sehingga nantinya dapat menjawab rumusan masalah yang dikemukakan dalam jurnal ini.

\section{HASIL DAN PEMBAHASAN Kuasa}

Pasal 1792 Kitab Undang-Undang Hukum Perdata (selanjutnya disebut KUH Perdata) menjelaskan bahwa "Pemberian kuasa adalah suatu perjanjian dengan mana seorang memberikan kekuasaan kepada seorang lain, yang menerimanya, untuk atas namanya menyelenggarakan suatu urusan". Seorang yang memberikan kekuasaan kepada orang lain untuk dan atas namanya menyelenggarakan suatu urusan disebut pemberi kuasa, sedangkan seorang lain yang menerima kuasa dari pemberi kuasa disebut penerima kuasa. Mengingat pemberian kuasa adalah sebuah perjanjian, maka dengan demikian perjanjian pemberian kuasa akan tunduk pada Pasal 1320 KUH Perdata yang 
mengatur mengenai syarat sahnya perjanjian, yaitu :
a. Sepakat mereka yang mengikatkan dirinya;
b. Kecakapan untuk membuat suatu perikatan;
c. Suatu hal tertentu;
d. Sebab yang halal.

Menurut Yahya Harahap (2012) mengutarakan bahwa akan disebut sebagai pemberian kuasa jika :
a. Pemberi kuasa melimpahkan perwakilan atau mewakilkan kepada penerima kuasa untuk mengurus kepentingannya, sesuai dengan fungsi dan kewenangan yang ditentukan dalam surat kuasa.

b. Dengan demikian, penerima kuasa berkuasa penuh, bertindak mewakili pemberi kuasa kepada pihak ketiga untuk dan atas nama pemberi kuasa.

c. Pemberi kuasa bertanggung jawab atas segala perbuatan kuasa, sepanjang perbuatan yang dilakukan kuasa tidak melebihi wewenang yang diberikan pemberi kuasa.

Suatu pemberian kuasamerupakan perjanjian sepihak dalam arti bahwa kewajiban untuk melaksanakan prestasi hanya terdapat pada satu pihak, yaitu pada penerima kuasa. Pemberian kuasa terjadi karena adanya machtiging yang merupakan pernyataan kehendak (sepihak) dari pemberi kuasa yang mengandung kemauan agar ia diwakili oleh penerima kuasa untuk melakukan tindakan hukum demi kepentingan dan atas nama pemberi kuasa. Dari pernyataan kehendak pemberi kuasa timbul suatu hak bagi penerima kuasa bukan kewajiban untuk melakukan tindakan hukum atas nama pemberi kuasa (Budiono, 2012). Jika diperjanjikan upah sebagaimana tercantum pada Pasal 1794 KUH Perdata, sifat perjanjian pemberian kuasa menjadi timbal balik, karena sekarang pemberi kuasa harus melaksanakan prestasi, yaitu memberikan upah kepada penerima kuasa.

Pasal 1793 KUH Perdata mengatur lebih lanjut mengenai mekanisme pemberian kuasa yang dapat dilakukan melalui : a. Tertulis (akta otentik, akta di bawah tangan, dan surat)

b. Tidak tertulis (lisan)

Walaupun pemberian kuasa dapat dilakukan secara lisan, Herlien Budiono (2012) mengingatkan bahwa kuasa lisan sangat sulit untuk dibuktikan.

Berdasarkan KUH Perdata, Pemberian kuasa berakhir karena :

a. Penarikan kembali kuasa oleh pemberi kuasa; (Pasal 1813 KUH Perdata)

b. Pemberitahuan penghentian kuasa dari pemberi kuasa; (Pasal 1813 KUH Perdata)

c. Pemberi kuasa dan penerima kuasa meninggal atau ditaruh di bawah pengampuan; (Pasal 1813 KUH Perdata)

d. Ditunjuknya seorang penerima kuasa baru untuk menjalankan urusan yang sama yang menyebabkan ditariknya (Pasal 1816 KUH Perdata).

Selain itu, secara umum pemberian kuasa akan berakhir jika :

a. Jangka waktu pemberian kuasa telah berakhir;

b. Penerima kuasa telah melaksanakan kuasa/semua tindakan hukum dari pemberi kuasa;

\section{RUPS}

c. Hal-hal lain yang disepakati.

RUPS sebagaimana didefinisikan oleh Pasal 1 angka 4 Undang-Undang Nomor 40 Tahun 2007 tentang Perseroan Terbatas (selanjutnya disebut UU PT) adalah "organ perseroan yang mempunyai wewenang yang tidak diberikan kepada direksi atau dewan komisaris dalam batas yang ditentukan dalam Undang-Undang ini dan/atau anggaran dasar".

Yahya Harahap

(2015) mendeskripsikan lebih lanjut kewenangan RUPS yang paling utama sesuai dengan UU PT 2007 adalah sebagai berikut :

1. Menyatakan menerima atau mengambil alih semua hak dan kewajiban yang timbul dari perbuatan hukum yang dilakukan pendiri atau kuasanya (Pasal 13 ayat (1));

2. Menyetujui perbuatan hukum atas nama Perseroan yang dilakukan semua anggota 
Direksi, semua anggota Dewan Komisaris bersama-sama pendiri dengan syarat semua pemegang saham hadir dalam RUPS, dan semua pemegang saham menyetujuinya dalam RUPS tersebut (Pasal 14 ayat (4));

3. Perubahan Anggaran Dasar (selanjutnya disebut AD) ditetapkan oleh RUPS (Pasal 19 ayat (1));

4. Memberi persetujuan atas pembelian kembali atau pengalihan lebih lanjut saham yang dikeluarkan Perseroan (Pasal 38 ayat (1));

5. Menyerahkan kewenangan kepada Dewan Komisaris guna menyetujui pelaksanaan keputusan RUPS atas pembelian kembali atau pengalihan lanjut saham yang dikeluarkan Perseroan (Pasal 39 ayat (1));

6. Menyetujui penambahan modal perseroan (Pasal 41 ayat (1));

7. Menyetujui pengurangan modal Perseroan (Pasal 44 ayat (1));

8. Menyetujui rencana kerja tahunan apabila $\mathrm{AD}$ menentukan demikian (Pasal 64 ayat (1) jo. ayat (3));

9. Memberi persetujuan laporan tahunan dan pengesahan laporan keuangan serta laporan tugas pengawasan Dewan Komisaris (Pasal 69 ayat (1));

10. Memutuskan penggunaan laba bersih, termasuk penentuan jumlah penyisihan untuk cadangan wajib dan cadangan lain (Pasal 71 ayat (1));

11. Menetapkan pembagian tugas dan pengurusan Perseroan antara anggota Direksi (Pasal 92 ayat (5));

12. Mengangkat anggota Direksi (Pasal 94 ayat (1));

13. Menetapkan tentang besarnya gaji dan tunjangan anggota Direksi (Pasal 96 ayat (1));

14. Menunjuk pihak lain untuk mewakili Perseroan apabila seluruh anggota Direksi atau Dewan Komisaris mempunyai benturan kepentingan dengan Perseroan (Pasal 99 ayat (2) huruf c);

15. Memberi persetujuan kepada Direksi untuk :

a. Mengalihkan kekayaan Perseroan, atau

\section{b. Menjadikan jaminan utang kekayaan}

Perseroan,

Persetujuan itu diperlukan apabila lebih dari 50\% (lima puluh persen) jumlah kekayaan bersih Perseroan dalam 1 (satu) transaksi atau lebih baik yang berkaitan satu sama lain maupun tidak (Pasal 102 ayat (1));

16. Memberi persetujuan kepada Direksi untuk mengajukan permohonan pailit atas Perseroan sendiri kepada Pengadilan Niaga (Pasal 104 ayat (1));

17. Memberhentikan anggota Direksi (Pasal 105 ayat (2));

18. Menguatkan keputusan pemberhentian sementara yang dilakukan Dewan Komisaris terhadap anggota Direksi (Pasal 106 ayat (7));

19. Mengangkat anggota Dewan Komisaris (Pasal 111 ayat (1));

20. Menetapkan tentang besarnya gaji atau honorarium dan tunjangan anggota Dewan Komisaris (Pasal 113);

21. Mengangkat Komisaris Independen (Pasal 120 ayat (2));

22. Memberi persetujuan atas Rancangan Penggabungan (Pasal 123 ayat (3));

23. Memberi persetujuan mengenai Penggabungan, Peleburan, Pengambilalihan, atau Pemisahan (Pasal 127 ayat (1));

24. Memberi keputusan atas pembubaran Perseroan (Pasal 142 ayat (1) huruf a);

25. Menerima pertanggungjawaban likuidator atas penyelesaian likuidasi (Pasal 143 ayat (1).

Menurut Yahya Harahap (2015) kemudian mengklasifikasikan pula syarat kuantitas kuorum kehadiran dan pengambilan keputusan bagi setiap agenda atau mata acara RUPS sebagai berikut :

1. Syarat kuorum kehadiran dan pengambilan keputusan RUPS mengenai mata acara biasa, diatur pada Pasal 86:

- Kuorum kehadirannya 1/2 (satu perdua) bagian dari jumlah seluruh saham dengan hak suara, hadir atau diwakili,

- Selanjutnya menurut Pasal 87 ayat (2), keputusan sah, jika disetujui lebih dari 
1/2 (satu per dua) bagian dari jumlah suara yang dikeluarkan.

2. Syarat kuorum dan pengambilan keputusan RUPS untuk jenis mata acara atau agenda "perubahan" $\mathrm{AD}$, diatur pada Pasal 88, dengan ketentuan sebagai berikut:

- Syarat kuorum kehadiran, paling sedikit 2/3 (dua per tiga) bagian dari jumlah seluruh saham dengan hak suara, hadir atau diwakili, dan

- Keputusan sah, jika disetujui paling sedikit 2/3 (dua per tiga) bagian dari jumlah suara yang dikeluarkan.

3. Syarat kuorum kehadiran dan pengambilan keputusan RUPS mengenai mata acara penggabungan, peleburan, pengambilalihan atau pemisahan, pengajuan permohonan agar Perseroan dinyatakan pailit, perpanjangan jangka waktu berdirinya dan pembubaran Perseroan, merujuk kepada Pasal 89 dengan ketentuan sebagai berikut :

- Syarat kuorum kehadiran, paling sedikit 3/4 (tiga per empat) bagian dari jumlah seluruh saham dengan hak suara, hadir atau diwakili,

- Keputusan sah, apabila disetujui paling sedikit 3/4 (tiga per empat) bagian dari jumlah suara yang dikeluarkan.

\section{Pemberian Kuasa Lisan untuk Mewakili}

\section{Pemegang Saham dalam RUPS}

Dalam hal pemegang saham tidak bisa menghadiri RUPS, maka pemegang saham tersebut dapat memberikan kuasa ke orang lain untuk mewakilinya di RUPS. Penerima kuasa akan mewakili pemegang saham untuk mempertahankan hak suaranya, baik untuk memenuhi persyaratan kuorum RUPS atau pengambilan keputusan RUPS. Yahya Harahap (2015) menjelaskan pendapat dari Walter Coon, bahwa hak suara merupakan hak yang melekat secara inherent pada diri setiap pemegang saham (is inherent in ownership of share). Berarti setiap pemegang saham berhak menghadiri dan berbicara serta mengeluarkan suara dalam RUPS.

Pemberian kuasa kepada orang lain untuk mewakili hak suara pemegang saham dapat pula dilakukan secara lisan, mengingat tidak ada aturan yang melarang pemberian kuasa secara lisan. Karena pemberian kuasa secara lisan lebih sederhana daripada pemberian kuasa secara tertulis, cukup sering orang melakukan pemberian kuasa secara lisan. Walaupun demikian, Herlien Budiono (2018, hal. 122) mengingatkan bahwa kuasa lisan sulit untuk membuktikannya. Pemberian kuasa akan lebih mudah untuk dibuktikan apabila dibuat secara tertulis.

Pemberian kuasa secara lisan juga sangat rawan menghasilkan masalah di kemudian hari. Sebagai contoh, apabila ternyata dalam RUPS dibicarakan agenda tertentu dan membutuhkan hak suara dari pemegang saham untuk mengambil keputusan. Bukan hal yang mustahil bagi penerima kuasa untuk menyalahgunakan hak suara yang sementara itu berada padanya untuk memberikan suara dalam pengambilan keputusan. Padahal belum tentu suara yang diberikan itu sesuai atau sejalan dengan apa yang diinginkan pemegang saham. Kondisi tersebut tentu berpotensi menghasilkan konflik antara pemegang saham sebagai pemberi kuasa dengan si penerima kuasa.

Hukum acara perdata Indonesia melalui Pasal 164 Herziene Indlandsch Reglement (selanjutnya disebut HIR) mengenal 5 (lima) macam alat bukti, yaitu :
1. Surat;
2. Saksi;
3. Persangkaan;
4. Pengakuan;
5. Sumpah.

Dalam hal terdapat permasalahan hukum terkait pemberian kuasa yang dilakukan secara tertulis, alat bukti langsung yang dapat digunakan adalah alat bukti surat, yaitu surat pemberian kuasa yang bersangkutan. Sedangkan jika terdapat permasalahan hukum terkait pemberian kuasa yang dilakukan secara lisan, maka pembuktian yang dapat dilakukan hanya dapat melalui 4 (empat) alat bukti lain secara tidak langsung, dan pembuktian tersebut susah untuk diwujudkan.

\section{KESIMPULAN}

Pemberian kuasa untuk mewakili hak suara pemegang saham dalam RUPS 
diperbolehkan mengingat terkadang pemegang saham tidak dapat menghadiri RUPS secara langsung karena satu dan lain hal. Pemberian kuasa tersebut dapat dilakukan secara tertulis dan lisan. Pemberian kuasa secara tertulis dapat lebih mudah dibuktikan dibandingkan dengan pemberian kuasa secara lisan. Pemberian kuasa secara lisan sulit untuk dibuktikan.

\section{SARAN}

Sebaiknya pembentuk undang-undang menyusun ketentuan yang secara tegas melarang pemberian kuasa secara lisan untuk mewakili pemegang saham dalam RUPS. Secara eksplisit juga sebaiknya ditentukan kewajiban membuat surat kuasa dalam bentuk tertulis, mengingat pembuktiannya yang jelas lebih mudah. Hal tersebut juga dilakukan mengingat pentingnya hak suara yang dikuasakan dalam memenuhi persyaratan kuorum RUPS dan pengambilan keputusan RUPS.

\section{UCAPAN TERIMA KASIH}

Terima kasih yang teramat sangat kepada pihak Jurnal Ilmu Sosial dan Pendidikan (JISIP) yang sangat membantu penulis dalam menyusun penelitian ini. Terima kasih juga kepada keluarga dan teman-teman yang senantiasa mendukung penulis.

\section{DAFTAR PUSTAKA}

Budiono, Herlien. 2012. Kumpulan Tulisan Hukum Perdata di Bidang Kenotariatan. Bandung: Citra Aditya Bakti. . 2018. Demikian Akta Ini. Bandung : Citra Aditya Bakti.

Harahap, Yahya. 2012. Hukum Acara Perdata. Jakarta : Sinar Grafika.

. 2015. Hukum Perseroan Terbatas. Jakarta : Sinar Grafika.

Latumeten, Pieter E. 2017. Reposisi Pemberian Kuasa dalam Konsep "Volmacht dan Lastgeving" berdasarkan Cita Hukum Pancasila. Jurnal Hukum \& Pembangunan. Vol. 47, No. 1. Fakultas Hukum Universitas Indonesia, Depok.
Marzuki, Peter Mahmud. 2015. Penelitian Hukum, Jakarta: Kencana Prenada Media Group.

Soemitro, Ronny Hanitijo. 1998. Metodologi Penelitian Hukum dan Jurimetri, Jakarta: Ghalia Indonesia.

Wicaksono, Frans Satriyo. 2009. Panduan Lengkap Membuat Surat-Surat Kuasa, Jakarta : Visi Media.

Wulandari, Purry. 2010. Pemberian Kuasa Lisan Untuk Melakukan Perbuatan Hukum yang Mengatasnamakan PT kepada Manajer Pemasaran (Studi Kasus Wanprestasi Perjanjian Jual Beli Dengan Kuasa Lisan yang Diberikan Direksi Kepada Manajer Pemasaran Dalam PT. Y.). Depok: Universitas Indonesia.

Herziene Indlandsch Reglement.

Kitab Undang-Undang Hukum Perdata.

Undang-Undang Dasar Negara Republik Indonesa Tahun 1945.

Undang-Undang Nomor 40 Tahun 2007 tentang Perseroan Terbatas. 